\title{
PENULISAN ARTIKEL ILMIAH UNTUK GURU SEKOLAH DASAR SE-KABUPATEN BANGKA
}

\author{
Sri Sugiyarti*, Nurfitriani, Rajab Vebrian \\ Sekolah Tinggi Keguruan dan Ilmu Pendidikan Muhammadiyah Bangka Belitung \\ email: sri.sugiyarti@stkipmbb.ac.id
}

\begin{abstract}
Writing article is an absolute requirement for teachers who will rise in rank and certain classes. In the fact, there are so many teachers to retirees only in the IV / a. The main problem is about credit numbers from sub-elements of scientific publications and / or elements of innovative work. This workshop aims to provide an understanding for elementary school teachers in writing article. The method used is a workshop that was held for two days with a total of 32 hours of learning hours. The results obtained from this workshop were an increase in teacher understanding of writing article and producing article papers from the teacher.
\end{abstract}

Keywords: Workshop, Article Writing, Bangka Regency, Elementary School Teachers.

\begin{abstract}
Abstrak
Menulis karya ilmiah merupakan syarat mutlak bagi guru yang akan naik pangkat dan golongan tertentu. Namun fakta di lapangan bahwa sebagian besar guru sampai purnabakti hanya pada golongan ruang IV/a. Kendala yang paling mendasar lambatnya kenaikan golongan ini adalah terdapat pada pemenuhan angka kredit dari sub unsur publikasi ilmiah dan/atau unsur karya inovatif. Workshop ini bertujuan untuk memberikan pemahaman bagi guru sekolah dasar dalam menulis karya tulis ilmiah.Metode yang digunakan adalah workshop yang dilangsungkan selama dua hari dengan total jam pembelajaran $32 \mathrm{jam}$. Hasil yang didapatkan dari workshop ini adalah meningkatnya pemahaman guru terhadap penulisan karya ilmiah dan menghasilkan karya tulis ilmiah dari guru.
\end{abstract}

Kata Kunci: Workshop, Karya Tulis Ilmiah, Kabupaten Bangka, Guru Sekolah Dasar

\section{PENDAHULUAN}

Pengembangan profesi guru adalah kegiatan guru dalam rangka pengamalan ilmu pengetahuan, teknologi dan ketrampilan untuk peningkatan mutu, baik bagi proses belajar mengajar dan profesionalisme tenaga kependidikan lainnya maupun dalam rangka menghasilkan sesuatu yang bermanfaat bagi pendidikan dan kebudayaan. Adapun kegiatan pengembangan profesi yang dimaksud adalah 1.) Membuat karya tulis/karya ilmiah di bidang pendidikan, 2.) menemukan teknologi di bidang pendidikan, 3.) membuat alat pelajaran/alat peraga atau alat bimbingan, 4.) Menciptakan karya tulis ilmiah, dan mengikuti kegiatan pengembangan kurikulum, (Depdiknas, 2001: 1). Maka menulis karya ilmiah merupakan syarat mutlak bagi guru yang akan naik pangkat dan golongan tertentu.

Pangkat, dan golongan ruang Pegawai Negeri Sipil (PNS) dalam jabatan fungsional, seperti guru dimulai dari pangkat penata muda, dan golongan III/ a sampai pada pangkat pembina utama, dan golongan IV/ e (Permenpanrb, 2009:9).

Berdasarkan BKN (2011:20) bahwa alur karier PNS secara reguler untuk lulusan pendidikan S.1/ D.IV, S.2, dan S.3 sampai pada golongan ruang IV/ e masing - masing memerlukan masa kerja 32 tahun, 28 tahun, dan 24 tahun. Jika Calon Pegawai Negeri Sipil (CPNS) lulusan pendidikan S.1/ D.IV usia 23 tahun, maka golongan ruang IV/ e diperoleh pada usia 55 tahun; jika CPNS lulusan pendidikan S.2 usia 25 tahun, maka golongan ruang 
IV/ e diperoleh pada usia 53 tahun, dan jika CPNS lulusan pendidikan S.3 usia 27 tahun, maka golongan ruang IV/ e diperoleh pada usia 51 tahun. Artinya setiap guru lulusan pendidikan S.1/ D.IV, S.2, dan S.3 dapat sampai pada golongan ruang IV/ e sebelum purnabakti, tetapi fakta di lapangan bahwa sebagian besar guru sampai purnabakti hanya pada golongan ruang $\mathrm{IV} / \mathrm{a}$.

Berdasarkan Peraturan Bersama Mendiknas dan KBKN (2010:22-23) bahwa setiap kenaikan golongan ruang terdiri dari sub unsur pengembangan diri, dan sub unsur publikasi ilmiah dan/ atau karya inovatif, kecuali kenaikan golongan ruang III/ a ke III/ b hanya dari sub unsur pengembangan diri. Selain itu, setiap kenaikan golongan ruang dipersyaratkan paling sedikit 3 (tiga) - 5 (lima) angka kredit dari sub unsur pengembangan diri, dan paling sedikit 4 (empat) - 20 (dua puluh) angka kredit dari sub unsur publikasi ilmiah dan/ atau unsur karya inovatif. Sementara kenaikan golongan ruang IV/ a ke IV/ b dan IV/ b ke IV/ c dipersyaratkan paling sedikit 4 (empat) angka kredit dari sub unsur pengembangan diri, dan paling sedikit 12 (dua belas) angka kredit dari sub unsur publikasi ilmiah dan/ atau unsur karya inovatif, namun kenaikan golongan ruang IV/ b ke IV/ c wajib melaksanakan presentasi ilmiah. Sedangkan fakta di lapangan bahwa kendala yang paling mendasar mengenai kenaikan golongan ruang seorang guru terdapat pada pemenuhan angka kredit dari sub unsur publikasi ilmiah dan/ atau unsur karya inovatif.

Menurut Permenpan (2009:8) bahwa publikasi ilmiah, dan karya inovatif merupakan salah 2 (dua) dari 4 (empat) unsur pengembangan keprofesian berkelanjutan. Sementara sub unsur publikasi ilmiah terdiri dari 2 (dua) macam, yakni (a) publikasi ilmiah atas hasil penelitian atau gagasan inovatif pada bidang pendidikan formal; dan (b) publikasi buku teks pelajaran, buku pengayaan, dan pedoman guru. Sedangkan sub unsur karya inovatif terdiri dari 4 (empat) macam, yakni (a) menemukan teknologi tepat guna; (b) menemukan/ menciptakan karya seni; (c) membuat/ memodifikasi alat pelajaran/ peraga/ praktikum; dan (d) mengikuti pengembangan penyusunan standar, pedoman, soal dan sejenisnya.

Berdasarkan Permenpan (2009:29-31) bahwa satuan hasil dari kegiatan sub unsur melaksanakan publikasi ilmiah, meliputi surat keterangan dan makalah pemrasaran; buku; karya tulis dalam majalah/ jurnal ilmiah; laporan; makalah; artikel ilmiah; modul/ diktat; dan karya hasil terjemahan. Selain itu, satuan hasil dari kegiatan sub unsur melaksanakan karya inovatif, meliputi hasil karya; alat pelajaran; alat peraga; alat praktik; dan surat keputusan. Adapun fokus satuan hasil yang penulis angkat pada kesempatan kali ini yaitu artikel ilmiah, mengingat penulis merupakan pengurus Jurnal Edutainment di STKIP Muhammadiyah Bangka Belitung sejak tahun 2017. Berdasarkan pengalaman penulis sebagai pengurus jurnal bahwa kendala yang paling mendasar mengenai artikel ilmiah seorang guru yaitu aturan tata tulis. Menurut hemat penulis bahwa hal tersebut dikarenakan guru kurang terlatih. Berdasarkan hasil pelatihan Ismaniati dkk. (2010:2) bahwa peserta pengabdian menjadi lebih paham tentang konsep dan aspek - aspek karya tulis ilmiah, serta cara penulisannya secara terstandar. Oleh karena itu, penulis tertarik untuk melakukan pelatihan ini, mengingat kendala yang ditemukan berasal dari Guru Sekolah Dasar di Kabupaten Bangka, maka pengabdian ini diberi judul "Workshop Penulisan Artikel Ilmiah untuk Guru Sekolah Dasar se-Kabupaten Bangka".

\section{METODE PENGABDIAN}

Metode yang digunakan didalam pengabdian ini adalah metode Workshop dengan materi menulis artikel dan publikasi artikel ke dalam jurnal. Setelah 
peserta mendapatkan materi dilanjutkan dengan pendampingan penyusunan artikel bagi guru yang sudah mempunyai PTK dengan total jam pembelajaran sebesar 32 jam.

\section{HASIL DAN PEMBAHASAN}

Kegiatan pelaksanaan pelatihan penulisan artikel ilmiah se-Kabupaten Bangka ini dilaksanakan di Aula Dinas Pendidikan Kabupaten Bangka yang dilaksanakan pada tanggal 19 sampai dengan 20 Maret 2019 yang diikuti oleh 30 pesertayang berasal dari guru sekolah dasar se Kabupaten Bangka.

Terselenggaranya kegiatan ini berdasarkan dukungan dari kampus STKIP Muhammadiyah Bangka Belitung melalui Lembaga Penelitian dan Pengabdian Masyarat (LPPM), dan didukung oleh Kepala Dinas Kabupaten Bangka Padli, S.Pd., M.Si., beserta staf dan para guru se-Kabupaten Bangka. Mulai dari proses pengajuan untuk dilakukan kegiatan pengabdian, kepala dinas sangat merespon positif, dan menerima dengan terbuka dengan kegiatan pelatihan tersebut. Bantuanbantuan yang diberikan oleh pihak Dinas Kabupaten Bangka berupa:

a. Penyebaran Undangan

Undangan hanya dikhususkan untuk guruguru Sekolah Dasar yang sudah mempunyai Penelitian Tindakan Kelas, yang disebarkan langsung oleh Dinas Pendidikan Kabupaten Bangka. Dan mendapatkan sambutan antusias dari guru.

b. Tempat Pelaksanaan

Kepala Dinas Pendidikan Kabupaten Bangka telah memberikan izin untuk menggunakan Aula Dinas Kabupaten Bangka dan dapat memuat semua guru yang mewakili sekolah masing-masing. Ruangan tersebut sudah dilengkapi dengan AC, sound system, dan LCD proyektor.

c. Waktu

Workshop dilaksanakan pada tanggal 19-20 Maret 2019 yang dihadiri oleh Kepala Dinas Pendidikan Kabupaten
Bangka yang sekaligus membuka kegiatan dan diikuti oleh 30 guru se Kabupaten Bangka.

Workshop ini juga dibantu oleh tiga mahasiswa Program Studi Pendidikan Guru Sekolah Dasar (PGSD) dan tiga mahasiswa Pendidikan Matematika (PMTK).

d. Hasil Pelaksanaan Kegiatan PPM

Kegiatan workshop ini dilaksanakan dengan dua tahap yaitu tahap pemaparan materi dan tahap pendampingan pembuatan artikel ilmiah. Pelaksanaan pelatihan dibuka oleh Kepala Dinas Pendidikan Kabupaten Bangka pada tanggal 19 Maret 2019, bertempat di Aula Dinas Pendidikan Kabupaten Bangka yang dilanjutkan dengan pelaksanaan pelatihan selama dua hari yakni hari Selasa dan Rabu tanggal 19 hingga 20 Maret 2019. Workshop hari pertama peserta diberikan materi diantaranya: "Motivasi Menulis Artikel" yang disampaikan oleh kepala LPPM Sri Sugiyarti, M.Pd. sekaligus ketua didalam program pelatihan tersebut, selanjutnya materi Kedua: "Menulis Artikel Merupakan bagian dari Seni" yang dipaparkan oleh Nurfitriani, M.Pd. merupakan anggota LPPM sekaligus anggota dari program Pengabdian tersebut, dan materi yang terakhir dengan tema: "Submit your manuscript with confidence" : disampaikan oleh Rajab Vebrian, M.Pd. Adapun hari kedua berupa pendampingan pembuatan outline karya tulis ilmiah dan cara submit ke jurnal, yang dipandu oleh ketiga pemateri.

Pembahasan Hasil Pelaksanaan Kegiatan PPM

Pada hari pertama pelaksanaan kegiatan para guru antusias mengikuti workshop hingga sore hari. Dalam setiap sesi materi selalu muncul pertanyaan-pertanyaan terkait dengan proses penulisan artikel ke dalam jurnal. Dari pelatihan ini terungkap masih banyak guru yang terhambat dalam menulis artikel karena berbagai kendala diantaranya lemahnya penguasaan 
teknologi komputer, dimana banyak dari mereka karena sudah berumur dan tidak terbiasa menggunakan komputer/laptop. Disamping itu guru juga tidak memiliki akses ke jurnal pendidikan sehingga mereka sering mempercayakan kepada orang tertentu dan dengan biaya tertentu untuk mengirimkan artikelnya. Bagi sebagian guru yang tidak memiliki kemampuan dalam menulis artikel sering mengambil jalan pintas dengan meminta orang lain menyusun artikelnya. Sebagaimana diakui oleh Kepala Dinas Pendidikan dalam sambutannya yang menyatakan masih banyak guru yang terhambat kenaikan pangkatnya dikarenakan ketidakmampuan dalam menyusun artikel ke jurnal Pertanyaan terbanyak yang muncul adalah bagaimana cara menyusun atau mengubah PTK kedalam artikel ilmiah. Pertanyaan lain yang banyak dikemukakan adalah susunan pembuatan artikel ilmiah (apa saja yang mesti dimasukkan dalam artikel). Namun demikian dari 30 peserta ada tiga guru yang sudah beberapa kali membuat PTK bahkan ada yang telah membuat buku.

Hari kedua pelaksanaan workshop, para guru berlatih menyusun artikel dari PTK masing-masing yang sebelumnya sudah disiapkan kemudian membuat outlines penulisan karya ilmiah. Peserta dibuat kelompok-kelompok dengan disampingi masing-masing satu nara sumber dalam hal ini tim pengabdian masyarakat.

Pada tahap ini artikel dari peserta langsung dibedahbersama-sama untuk melihat kekurangan dalam penulisan dan hal-hal lainnya.

\section{SIMPULAN}

Berdasarkan hasil pelaksanaan Program Workshop yang bertema Penulisan Karya Tulis Ilmiah bagi Guru-guru SD sekabupaten Bangka, yang dilaksanakan pada tanggal 19 dan 20 Maret 2019 di Aula Dinas Kabupateng Bangka Provinsi Bangka Belitung dapat disimpulkan halhal sebagai berikut. a. Pemahaman guru-guru SD terhadap Karya Tulis Ilmiah dan Penelitian Tindakan Kelas meningkat dari sebelum pelatihan dan sesudah mereka mengikuti pelatihan.

b. Pemahaman guru terhadap cara mencari dan menemukan ide sampai pelaporan Karya Tulis Ilmiah meningkat lebih baik dibanding sebelum mengikuti pelatihan.

c. Pengaruh pelatihan Karya Tulis Ilmiah dalam upaya meningkatkan profesionalisme guru sangat baik karena dapat meningkatkan motivasi mengajar, menjamin transparansi pengabdian dan pada akhirnya dapat meningkatkan profesionlisme guru.

d. Perlu ada pelatihan dan kerjasama yang berkesinambungan antara pihak Kampus STKIP MBB dalam mengembangkan Karya Tulis Ilmiah dan Penelitian Tindakan Kelas baik di sekolah-sekolah sekepulauan Bangka Belitung.

b. Pemerintah dapat memberikan Dana Bantuan seperlunya bagi penyusunan Karya Tulis Ilmiah dan Penelitian Tindakan Kelas di sekolah-sekolah, sehingga pelatihan ini dapat memberikan manfaat yang lebih besar bagi profesionalisme guru Sekolah Dasar.

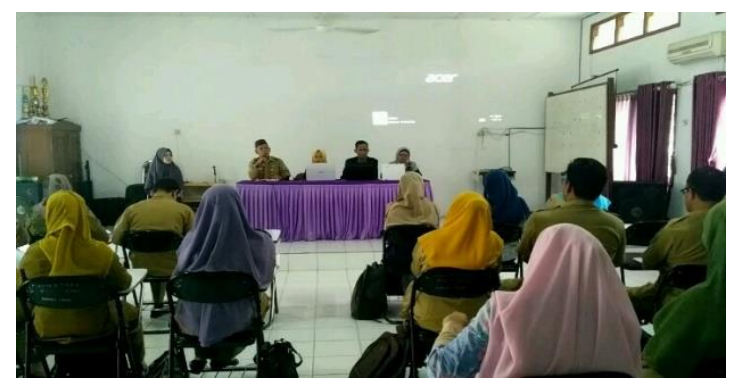

Foto 1. Pembukaan oleh Kepala Dinas Pendidikan kabupaten Bangka 


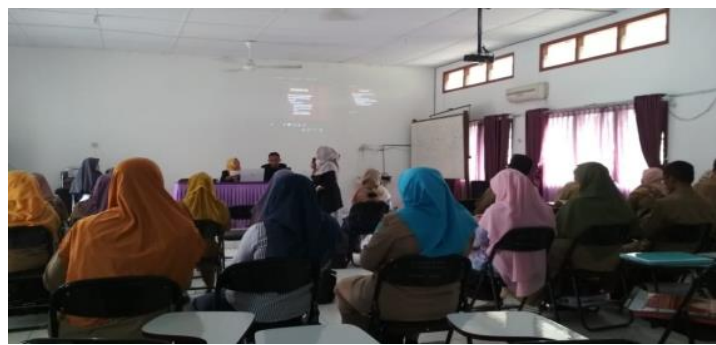

Foto 2. Proses Pemaparan Materi Pelatihan

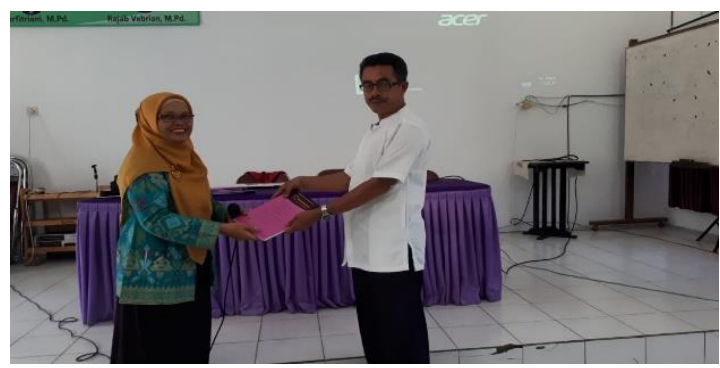

Foto 3. Pemberian Penghargaan bagi Guru

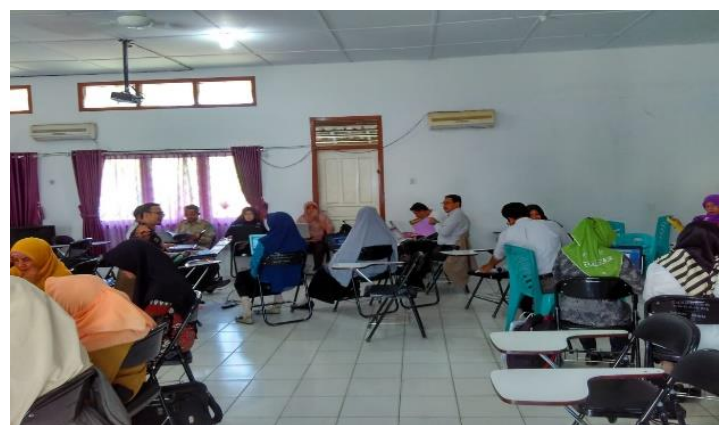

Foto 4. Pendampingan Penyusunan Artikel

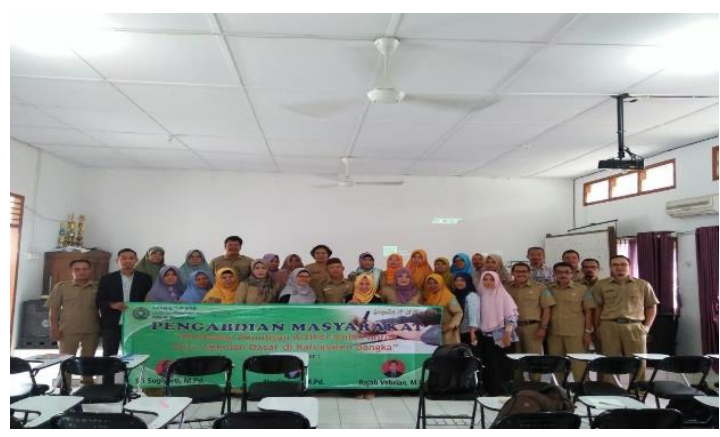

Foto 5. Penutupan

\section{UCAPAN TERIMAKASIH}

Ucapan terimakasih kami sampaikan kepada pihak Kampus STKIP Muhammadiyah Bangka Belitung yang setiap tahun memberikan peluang bagi dosen untuk melakukan pengabdian masyarakat melalui Program Hibah Penelitian dan Pengabdian, dan kepada pihak Dinas Pendidikan Kabupaten
Bangka yang telah memberikan ijin serta membantu dalam melaksanakan kegiatan ini, mahasiswa dan tim guru yang telah berpartisipasi dalam kegiatan, serta semua pihak yang ikut membantu dalam kegiatan ini.

\section{DAFTAR PUSTAKA}

[1]. BKN. 2011. Pedoman Penyusunan Pola Karier Pegawai Negeri Sipil. Jakarta: BKN.

[2]. Christina, dkk. 2010. Pelatihan Penulisan Karya Ilmiah bagi Kepala Sekolah Menengah Pertama Negeri di Lingkungan Dinas Pendidikan Dasar se - Kabupaten Bantul. Yogyakarta: UNY

[3]. Permenpanrb. 2009.2 Jabatan Fungsional Guru dan Angka Kreditnya. Jakarta: Menpanrb

[4]. Permendiknas dan KBKN. 2010. Petunjuk Pelaksanaan Jabatan Fungsional Guru dan Angka Kreditnya. Jakarta: Mendiknas dan KBKN. 